\title{
Changes in soil exchangeable nutrients across different land uses in steep slopes of Mizoram, North-east India
}

\author{
Etsoshan Y Ovung \\ Department of Forestry, Mizoram University, Tanhril, Aizawl - 796004 (Mizoram), India \\ S. K. Tripathi* \\ Department of Forestry, Mizoram University, Tanhril, Aizawl - 796004 (Mizoram), India \\ Francis Q Brearley \\ Department of Natural Sciences, Manchester Metropolitan University, Chester Street, \\ Manchester, M1 5GD, UK \\ *Corresponding author. Email: sk_tripathi@rediffmail.com
}

\section{How to Cite}

\section{Article Info}

https://doi.org/10.31018/ jans.v13i3.2795

Received: June 28, 2021

Revised: August 6, 2021

Accepted: August 9, 2021

Ovung, E. Y et al. (2021). Changes in soil exchangeable nutrients across different land uses in steep slopes of Mizoram, North-east India. Journal of Applied and Natural Science, 13(3), 929 - 936. https://doi.org/10.31018/jans.v13i3.2795

\begin{abstract}
Land use change resulting from anthropogenic pressure on land has led to degraded soil quality, especially in the hilly tropical regions where ecosystems are generally fragile and susceptible to soil degradation from cultivation. Hence, sustainable land uses and management practices are crucial for agricultural production and ecological balance, particularly in these regions. The present study investigates the impact of various hill land uses (Natural forest-NAF, Jhum fallow-JF, Home garden-HG, Acacia pennata plantation-AP and Current Jhum-CJ) on soil exchangeable nutrients in steeply sloping agro-ecosystems of Mizoram, North-east India. Soil samples were collected from three different depths (0-10, 10-20 \& 20-30 cm) and analyzed for $\mathrm{pH}$, $\mathrm{P}_{\text {avail }}$, $\mathrm{Na}, \mathrm{K}, \mathrm{Mg}, \mathrm{Mn}$ and $\mathrm{Ca}$. Our results indicated that land use and soil depths had a significant impact on soil $\mathrm{pH}, \mathrm{P}_{\text {avail }}$ and soil exchangeable cations $(p<0.05)$. Conversion of native forests for cultivation negatively affected soil properties as indicated by the reduced soil exchangeable cations in cultivated lands (AP \& CJ) in relation to the natural forest (NAF) and Jhum fallow (JF). Soils under longer periods of fallow ( $>12$ years) led to increases in soil available nutrients indicating the role of vegetation cover in conserving and enhancing soil available nutrients and vice-versa. In addition, Home garden (HG) showed moderately higher available soil nutrients signifying the role of sustainable management practices such as the addition of organic amendments and mixed cropping, leading to increased soil available nutrient content.
\end{abstract}

Keywords: Anthropogenic pressure, Exchangeable nutrients, Land use change, Sustainability

\section{INTRODUCTION}

Land use change induced by anthropogenic actions has been a major issue in the past few decades, fuelled by the alarming rate of growth in human populations. This has exerted immense pressure on Earth's most valuable natural resources, such as forest ecosystems and their soils. Globally, land use change and management practices are the most dominating factors that influence soils' major properties and ecological processes (Lal, 2001; Tripathi et al., 2012; Valle Junior et al., 2014; Pacheco et al., 2018). Unsustainable land use and management practices which lead to soil health deterioration can be regarded as a severe challenge for food security and environmental sustainability worldwide (Lal, 2009). However, this issue is more pronounced in the developing regions experiencing pres- sure due to an increase in the human population (Pricope et al., 2013; Tully et al., 2015) and where conversion of natural forests and grasslands to other land uses such as croplands and uncontrolled grazing have degraded the soil properties (Gregory et al., 2015; Valera et al., 2016).

The impact of land use change on soil properties is more pronounced in the hilly regions as it can greatly degrade soil quality with increased soil loss through runoff and erosion (Singh et al., 2015; Wapongnungsang et al., 2018; Lalnunzira and Tripathi, 2018). Shifting cultivation (Jhum) is a major issue in most tropical regions, especially in North-east India, where this practice is the most prominent form of agriculture, leading to loss of vegetation cover while inducing land use change. The decrease in the fallow period has led to soil degradation, while the increase in the fallow period 
following shifting cultivation has been observed to enhance SOM and increase nutrient content due to changing belowground dynamics (Wapongnungsang et al., 2017; Hauchhum and Tripathi, 2017; Singha and Tripathi, 2017). The study area (Mizoram) is characterized by extreme slopes and undulating physiographic conditions. Thus, cultivation under such conditions becomes intricate, thereby threatening the region's sustainability by affecting the primary source of livelihood for the majority of the rural population of Mizoram (Tripathi et al., 2017).

Shifting cultivation is one of the major farming practices that cause land degradation due to shortening the fallow length. Therefore, it is necessary to develop policies and strategies aimed at sustainable Jhum farming systems or other sustainable farming alternatives in the state to minimize deforestation and loss of soil fertility (Grogan et al., 2012; Tripathi et al., 2017). Appropriate soil management practices and other favourable integrated land use management activities are indispensable in maintaining soil physical, chemical and biological properties. Therefore, it is crucial to evaluate the impacts of land use activities on soil properties and fertility for sustainable agricultural productivity (Fesha et al., 2002). However, studies are still limited in the Northeast region of India on qualitative changes in the soil (Singh et al., 2015; Manpoong et al., 2019; Ovung \& Tripathi, 2020; Ovung et al., 2021). In order to overcome undesirable changes in soil properties leading to reduced productivity and poor ecosystem functioning due to land use change, there is a need to understand how the soil responds to a particular land use system. This study was an attempt to quantify and study the pattern of changes in exchangeable nutrients under soils of various land uses in steep slopes of Mizoram, North-east India.

\section{MATERIALS AND METHODS}

\section{Study area}

Mizoram is a hilly state located at the southernmost part of the North-east region of India, lying between $92^{\circ} 15^{\circ}$ to $93^{\circ} 29^{\prime} \mathrm{E}$ Long and $21^{\circ} 58^{\prime}$ to $24^{\circ} 35^{\prime} \mathrm{N}$ Lat, and covers an area of $21,081 \mathrm{~km}^{2}$ (Fig 1.), endowed with considerable coverage of green foliage amounting to about $85.4 \%$ of its total geographical area under forest area (India State of Forest Report, 2019). The state enjoys a moist sub-tropical to moist tropical climate and the region is influenced by monsoons, raining heavily from May to September with little rain in the dry winter season. The mean min and max temperature vary from $9^{\circ} \mathrm{C}$ to $24^{\circ} \mathrm{C}$ during winter and $24^{\circ} \mathrm{C}$ to $32^{\circ} \mathrm{C}$ during summer (Tripathi et al., 2017). The state receives an annual rainfall of about $2100 \mathrm{~mm}-3000 \mathrm{~mm}$. Inceptisols are the most common soil order found in the state, which are generally composed of sandy loam and clay loamy soil with high organic carbon richness (Colney and Nautiyal, 2013).

\section{Description of study sites}

The study sites fall within the two adjoining districts of Aizawl and Mamit, which share a similar type of climate, vegetation and soil. Five different land use systems, namely; Acacia pennata plantation (AP); Home garden (HG); Current Jhum (CJ); 12-15 years old Jhum fallow (JF), along with a Natural forest (NAF) were selected for the experiment from the two districts. A total of 15 study sites ( 5 land use types $\times 3$ site replicates) were located and identified within the two districts.

\section{Soil sampling}

Replicated soil samples were randomly collected from each site by inserting a $10 \mathrm{~cm}$ scaled soil corer having an inner diameter of $5.2 \mathrm{~cm}$. Soil samples were drawn from three different depths i.e. $0-10 \mathrm{~cm}, 10-20 \mathrm{~cm}$ and 20-30 cm. Within each site, samples were collected from 2 locations and composited for each depth as a single replicate and this way 3 random soil samples were collected. A total of 90 samples (2 composite samples $\times 3$ depths $\times 3$ site replicates $\times 5$ land use types) were collected for this study.

\section{Soil laboratory analysis}

Soil $\mathrm{pH}$ was measured on the basis of the potentiometric principle (Peech, 1965) in a 1:2.5 soil/water solution using a $\mathrm{pH}$ meter. For the analysis of soil exchangeable nutrients ( $\mathrm{P}_{\text {avail, }} \mathrm{Ca}, \mathrm{Mg}, \mathrm{Na}, \mathrm{K}$ and $\mathrm{Mn}$ ) air dried soil samples were extracted in Mehlich-I solution $\left(0.05 \mathrm{M} \mathrm{HCl}+0.025 \mathrm{M} \mathrm{H}_{2} \mathrm{SO}_{4}\right)$ and analyzed using the inductively coupled plasma spectrometer (iCAP6300 series, Thermo scientific).

\section{Statistical analysis}

The data obtained are presented as mean and standard error (SE). The resulting data were subjected to a two-way analysis of variance (ANOVA). Significant differences among soil variables were determined and the least significant difference (LSD) were calculated to determine significant differences between means at $p$ $\leq 0.05$. All statistical analysis was carried out using open source OPSTAT (free Online Agriculture Data Analysis Tool developed by O.P. Sheoran, Computer Programmer at CCS HAU, Hisar, India).

\section{RESULTS AND DISCUSSION}

\section{Effect of land use and soil depths on soil $\mathrm{pH}$ and $P_{\text {avail }}$}

Soil $\mathrm{pH}$ was acidic in all the land use systems and the value decreased with increasing depth. Soil $\mathrm{pH}$ was highest in CJ (5.4) and lowest in AP (4.7) at the surface soil layer (Table 1). Soil pH significantly varied among 


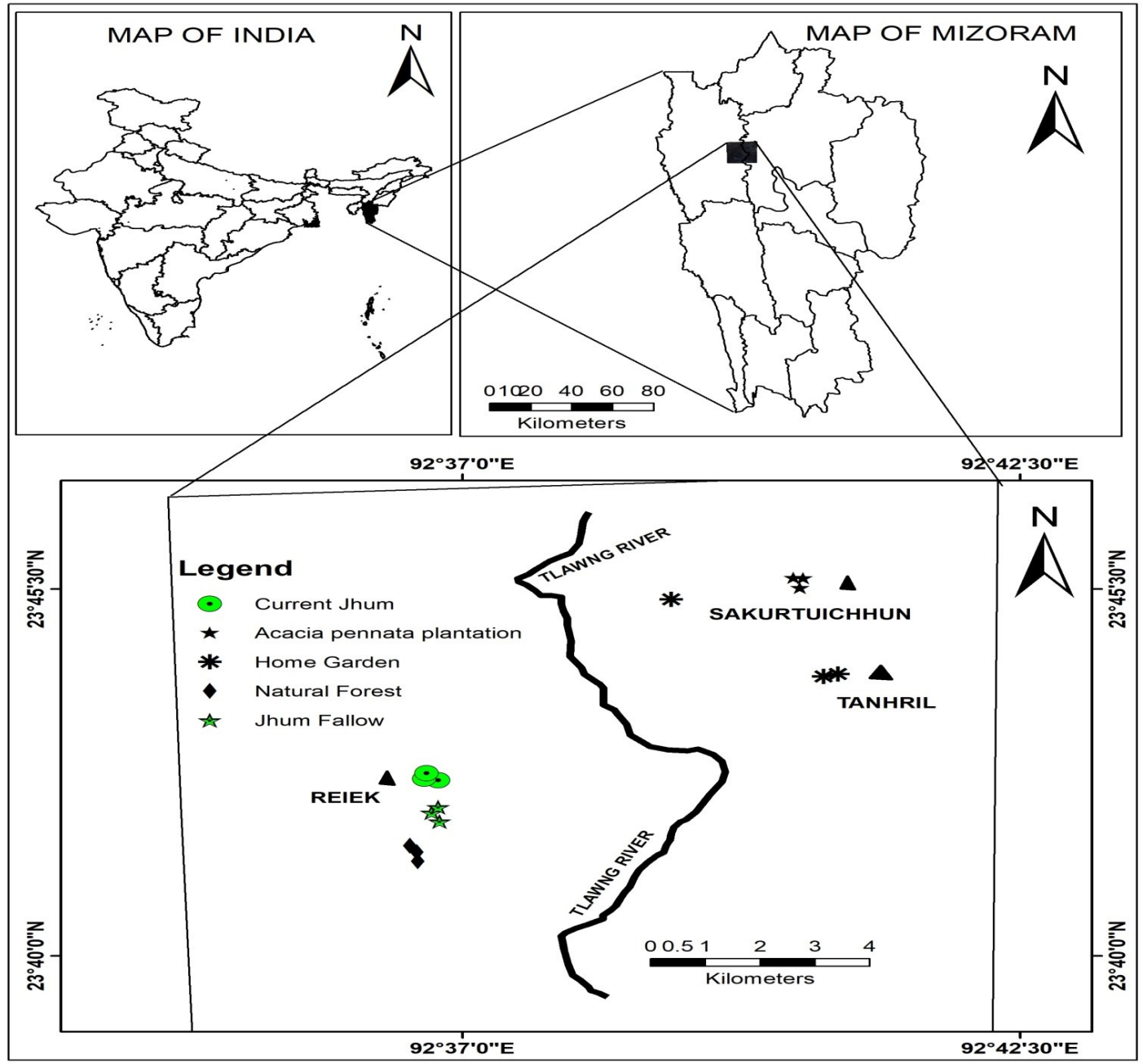

Fig. 1. Map showing study area and different land use systems (study sites) in Aizawl and Mamit districts of Mizoram, North-east India.

different land use systems (L) and soil depths (D) $(\mathrm{p}<0.05)$. Soil $\mathrm{pH}$ was highly acidic at the sub-surface soil depths $(10-20$ and $20-30 \mathrm{~cm})$ in all the land uses. Higher soil pH in the surface layer of $\mathrm{CJ}$ is well attributed to the release of cations as a result of the traditional slash and burn technique in the CJ land use system. Burning enhances the release of nutrients in the soil and thus increasing the soil pH (Moraes et al., 1996). The higher values of $\mathrm{pH}$ in the cultivated lands (HG, AP and $\mathrm{CJ}$ ) may also result from the conversion of natural forest into cultivation, which leads to an increment in $\mathrm{pH}$ at the surface and the sub-surface soil layers (Lumbanraja et al., 1998). The present values of $\mathrm{pH}$ are in accordance with other findings from the study area, indicating a strongly acidic nature of reaction in these soils (Grogan et al., 2012; Tripathi et al., 2017; Lungmuana et al., 2017).

$P_{\text {avail }}$ concentrations in soil were significantly affected by different land use systems (L), soil depths (D) and their interactions $(L x D)(p<0.05)$. The highest value at the surface layer $(0-10 \mathrm{~cm})$ was reported from HG followed by JF and the least in AP with values of 30.83 ,
20.35 and $7.26 \mathrm{mg} \mathrm{kg}^{-1}$, respectively (Table 1). Highest $P_{\text {avail }}$ in $H G$ at the surface layer $(0-10 \mathrm{~cm})$ may be related to the addition of organic manure in the form of animal waste by the land owners. Whereas the moderately higher $P_{\text {avail }}$ in JF and NAF may be attributed to net $P$ mineralization as a result of the continuous addition and input of leaf and root litters in these land uses. Sarkar et al. (2010) reported that $P_{\text {avail }}$ of soil increased with the addition and presence of litter on the soil surface. In comparison, the decrease in soil $P_{\text {avail }}$ with increasing soil depth may also be linked to the decrease SOM content that contributes significantly to the $\mathrm{P}$ pool in the soils of the study area. In addition, SOM influences $\mathrm{P}_{\text {avail }}$ through anion replacement of $\mathrm{H}_{2} \mathrm{PO}_{4}$ from adsorption sites and the formation of organophosphate complexes which are readily taken up by plants as reported in different studies (Tripathi et al., 2012; Nega and Heluf, 2013; Yihenew and Getachew, 2013). Our values of $P_{\text {avail }}$ falls within the range of low to medium among the various land use systems and soil depths as per the range of Cottenie (1980). In addition, studies by Tekalign et al. (2002) and Abebe and Endalkachew 


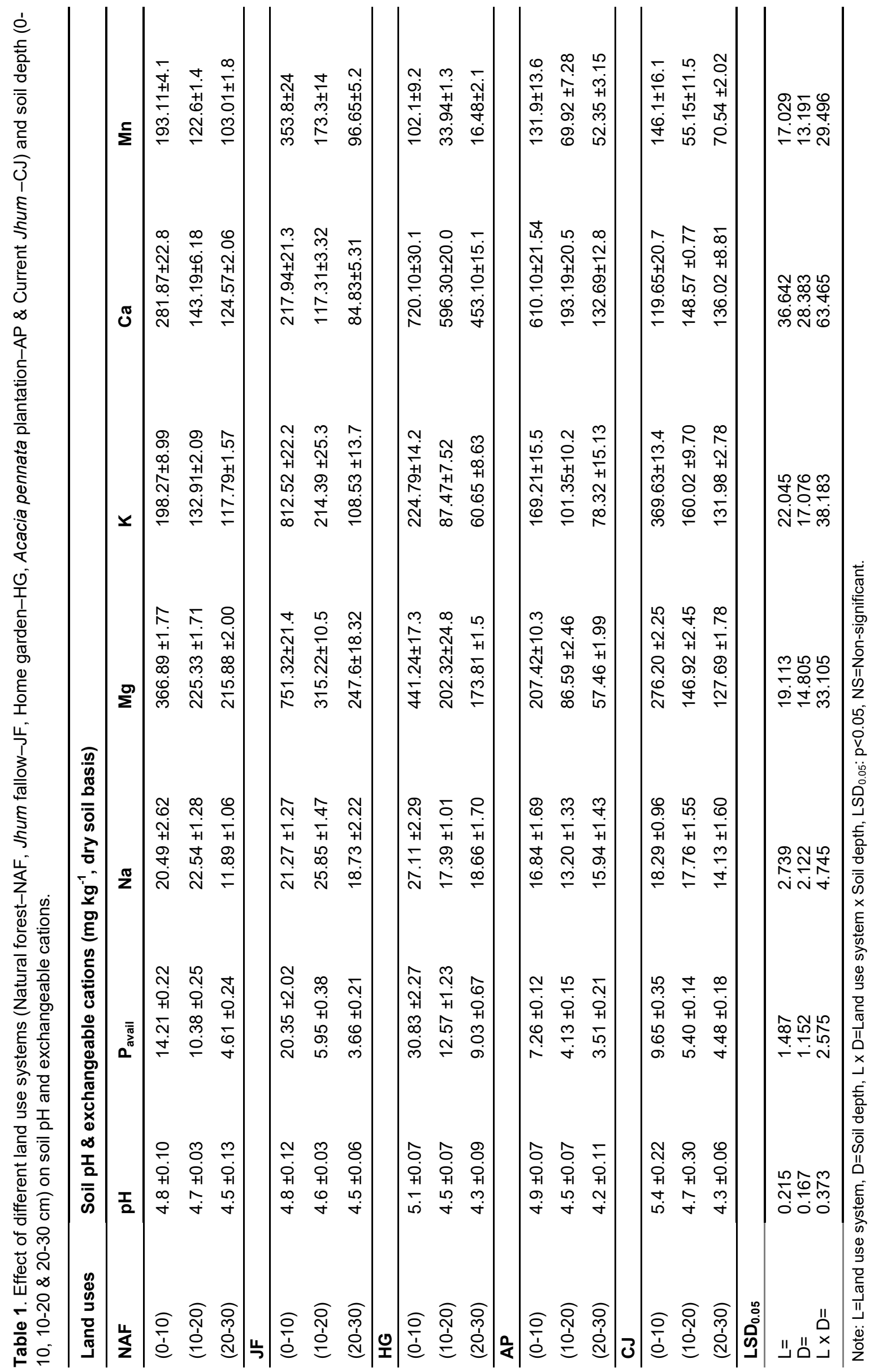


(2012) reported that $P_{\text {avail }}$ in Inceptisols and Vertisols are typically low as a result of various processes such as erosion, fixation and abundant crop harvests, especially in tropical regions.

\section{Effect of land use and soil depths on exchangeable cations ( $\mathrm{Na}, \mathrm{Mg}, \mathrm{K}, \mathrm{Ca} \& \mathrm{Mn}$ )}

The highest concentrations of exchangeable $\mathrm{Mg}, \mathrm{K}$ and $\mathrm{Mn}$ were recorded from JF in all the soil depths among all the land uses studied. In the surface layer $(0-10 \mathrm{~cm})$, the concentrations of $\mathrm{Mg}, \mathrm{K}$ and $\mathrm{Mn}$ in JF were 751.3 , 812.5 and $353.8 \mathrm{mg} \mathrm{kg}^{-1}$, respectively (Table 1 ). The concentrations of $\mathrm{Mg}\left(207.4 \mathrm{mg} \mathrm{kg}^{-1}\right)$ and $\mathrm{K}(169.2 \mathrm{mg}$ $\left.\mathrm{kg}^{-1}\right)$ in the surface layer $(0-10 \mathrm{~cm})$ were minimum in AP. However, $\mathrm{Mn}$ and Ca were low in HG (102.1 mg kg $\left.{ }^{-1}\right)$ and CJ $\left(119.7 \mathrm{mg} \mathrm{kg}^{-1}\right)$ at the surface layer $(0-10$ $\mathrm{cm})$. Ca concentration was substantially higher in HG than other land uses in all soil depths with values amounting to $720.1,315.2$ and $247.6 \mathrm{mg} \mathrm{kg}^{-1}$ at the 0 $10,10-20$ and $20-30 \mathrm{~cm}$ soil depths, respectively. The highest $\mathrm{Na}$ content was reported from $\mathrm{HG}$ with a value of $27.11 \mathrm{mg} \mathrm{kg}^{-1}$ and least in AP with a value of 16.84 $\mathrm{mg} \mathrm{kg}^{-1}$ (Table 4.3) in the surface layer $(0-10 \mathrm{~cm})$. Cation vales were significantly affected by different land use systems (L), soil depths (D), along with their interaction $(L x D)(p<0.05)$. As a general trend, $\mathrm{Mg}, \mathrm{K}, \mathrm{Ca}$, and $\mathrm{Mn}$ reflected depreciating values with increasing depth in all the land use systems (Table 1). Soil exchangeable cations ( $\mathrm{Na}, \mathrm{Mg}, \mathrm{K}, \mathrm{Ca} \& \mathrm{Mn}$ ) were significantly affected by different land use systems, soil depths and an interaction effect of both factors, which are in accordance with various other studies from semitropical and tropical regions of Nigeria and Ethiopia (Aytenew and Kibret, 2016; Ufot et al., 2016). The higher values of exchangeable $\mathrm{Mg}, \mathrm{K}$ and $\mathrm{Mn}$ in JF may be related to the emergence and presence of herbaceous vegetation and canopy cover that sheltered the soil, evading the soil from the direct impact of rainfall and minimising the loss of nutrients through runoff and erosion. In addition, Ramakrishnan and Kushwaha (2001) indicated that longer fallow periods (>20 years) tends to conserve more soil available nutrients leading to better crop productivity in comparison to younger fallow lands. The length of fallow period plays a vital role in promoting soil nutrients; therefore, longer period of fallow favours nutrient conservation (Ovung and Tripathi, 2020). Wapongnungsang et al., (2017) also indicated that a fallow period of more than 10 years leads to greater soil conservation of nutrients than shorter fallow during cultivation throughout the cropping season. The elevated levels of $\mathrm{P}_{\text {avail }}, \mathrm{Na}$ and $\mathrm{Ca}$ concentrations in $\mathrm{HG}$ may be attributable to the application of animal and household waste like dung and ash since these amendments are an important source of $\mathrm{Ca}, \mathrm{P}, \mathrm{K}$ and other nutrients (Voundi Nkana, 1998; Ovung et al., 2021). In addition, incorporation of conservation tillage, manure application and adoption of integrated agroforestry-based cropping systems are vital in minimizing adverse impacts on soil quality and efficient use of nutrients (Loria et al., 2016). In comparison to the other land use systems, the lower values of exchangeable $\mathrm{Na}, \mathrm{Mg}, \mathrm{K}, \mathrm{Ca}$ and $\mathrm{Mn}$ in cultivated soils of $A P$ and $C J$ may also be attributed to the nutrient uptake by plants for their growth and development. In the present study, lower values of exchangeable $\mathrm{Na}, \mathrm{K}, \mathrm{Ca}$ and $\mathrm{Mg}$ in cultivated lands (AP and $\mathrm{CJ}$ ) with higher concentrations in the surface layer $(0-10$ $\mathrm{cm}$ ) were in conformity with the study carried out by Yimer et al. (2008) in Ethiopia where the values of the elements were observed to be lower in cultivated lands than in grasslands or native forests. The greater concentration of $\mathrm{Mg}, \mathrm{K}, \mathrm{Ca}$ and $\mathrm{Mn}$ in the surface layer (0$10 \mathrm{~cm})$ than the sub-surface layers $(10-20 \& 20-30 \mathrm{~cm})$ can be related to the higher availability of plant and animal residues in the surface layer than beneath. Furthermore, it can also be attributed to vegetation's role, which pumps the bases from sub-surface layer to surface layers (Yimer et al., 2008). Our findings are also in accordance with the work of Kiflu and Beyene (2013) where they indicated higher nutrient content in the surface soil layer as a result of organic residue accumulation and related biological activity across different land uses in southern Ethiopia.

\section{Effect of land use and soil depths on cation ex- change capacity (CEC)}

Cation exchange capacity (CEC) was highest in JF at the surface layer with a value of $9.53 \mathrm{c} \mathrm{mol} \mathrm{kg}{ }^{-1}$. Whereas, in HG the same was higher in 10-20 and 20$30 \mathrm{~cm}$ soil depth with values of 4.94 and $3.91 \mathrm{c} \mathrm{mol} \mathrm{kg}$ 1 , respectively (Fig. 2). The lowest values of CEC at the surface layer $(0-10 \mathrm{~cm})$ was reported from CJ $(3.90 \mathrm{C}$ $\left.\mathrm{mol} \mathrm{kg}{ }^{-1}\right)$. However, the same in AP was lower in 10-20 and $20-30 \mathrm{~cm}$ with values of $2.01 \mathrm{c} \mathrm{mol} \mathrm{kg}^{-1}$ and $1.41 \mathrm{c}$ $\mathrm{mol} \mathrm{kg}{ }^{-1}$. The CEC across various land uses ranged from 3.90 to $9.53 \mathrm{c} \mathrm{mol} \mathrm{kg}^{-1}$ at the surface layer $(0-10$ $\mathrm{cm})$. CEC was also observed to change in all the land use systems with a decrease with increasing soil depths. Land use systems (L), soil depths (D) and interaction of both these factors were observed to have a significant effect $(p<0.05)$ on the soil CEC concentrations. The highest CEC in the surface layer of JF may be attributed to the greater vegetation cover and less disturbances to the soil in comparison to other land use systems. In contrast, the highest CEC at the 10-20 and 20-30 cm soil layer of HG may be related to the continuous organic amendments and their subsequent leaching down the depth. Our findings have some vital implications and indicate that CEC changes are susceptible to changes in management practices such as use of organic amendments and other inherent properties 


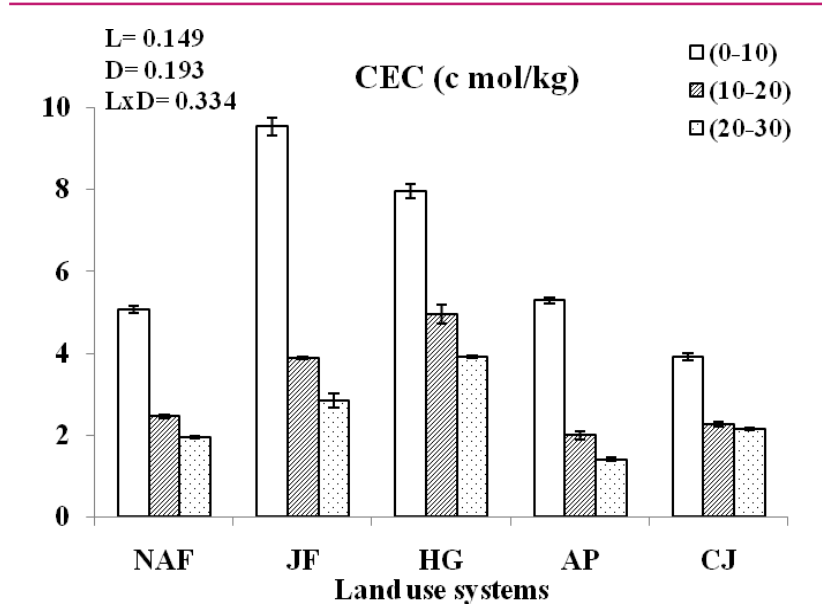

Fig. 2. Effect of land use systems (Natural forest-NAF, Jhum fallow-JF, Home garden-HG, Acacia pennata plantation-AP \& Current Jhum-CJ) and soil depths (0-10, 1020 \& 20-30 cm) on soil ECEC concentrations. ( $L=$ Land use system, $D=$ Soil depth, $L x D=L$ and use system $x$ Soil depth, $L S D_{0.05}: p<0.05, N S=$ Non-significant).

such as soil particle size distribution and SOC content in the soil. Ovung et al. (2021) also indicated that CEC values are susceptible to changes in land uses and have a significant impact on their values in the soil surface layer across various land use systems in Mizoram. Wu (2011) further grouped CEC values of $<10 \mathrm{c} \mathrm{mol} \mathrm{kg}$ ${ }^{1}, 10-20 \mathrm{c} \mathrm{mol} \mathrm{kg}^{-1}$ and $>20 \mathrm{c} \mathrm{mol} \mathrm{kg}^{-1}$ as weak, moderate, and high fertility soils. Our values of CEC ranged from 3.90 to $9.53 \mathrm{c} \mathrm{mol} \mathrm{kg}^{-1}$ across the various land use systems and soil depths and fall under the classification of weak fertility as given by Wu (2011).

\section{Conclusion}

The present study concluded that the clearing of native forests for cultivation led to negative feedbacks on soil properties as indicated by the poorer soil exchangeable cations ( $P_{\text {avail, }} \mathrm{Na}, \mathrm{Mg} \& \mathrm{~K}$ ) in cultivated lands (AP and $\mathrm{CJ}$ ) in relation to natural forest and fallow lands in Mizoram, North-east India. Soils with longer fallow length, as in the case of JF land use with a fallow length of $>12$ years, exhibited positive changes in soil available nutrients including $\mathrm{Mn}, \mathrm{K}, \mathrm{Mg}$ and $\mathrm{P}_{\text {avail }}$, indicating the role of vegetation cover in conserving available soil nutrients. The present findings signify that conversion of native forests and fallow lands to various land use induces degradation of soil quality and disrupts sustainability and conventional functioning of ecosystems due to different management practices. It is also suggested that in order to balance the loss in soil exchangeable nutrients due to land use change, there is a need to incorporate sustainable practices viz., terracing, mixed cropping, the addition of organic residues, mulching, cover crops, minimum tillage farming practices and other approaches aimed at conservation and rejuvena- tion of soil exchangeable nutrients in steeply sloped tropical regions.

\section{ACKNOWLEDGEMENTS}

We thank Manchester Metropolitan University for funding the first author's visit to the UK through a QR GCRF allocation and David McKendry for assistance with ICP analyses.

\section{Conflict of interest}

The authors declare that they have no conflict of interest.

\section{REFERENCES}

1. Abebe, N. \& Endalkachew, K. (2012). The contribution of coffee agro-ecotype to soil fertility in Southwestern Ethiopia. African Journal of Agricultural Research, 7(1), 74-81. https://doi.org/10.5897/AJAR11.1566

2. Aytenew, M. \& Kibret, K. (2016). Assessment of soil fertility status at Ddawja watershed in Enebse Sar Midir district, Northwestern Ethiopia. International Journal of Plant \& Soil Science 11(2), 1-13. https://doi.org/10.9734/IJPSS/20 $16 / 21646$

3. Colney, L. \& Nautiyal, B.P. (2013). Characterization and evaluation of soils of Aizawl district, Mizoram, India using remote sensing and GIS techniques. Journal of Geomatics, 7(1), 83-91.

4. Cottenie, A. (1980). Soil and plant testing as a basis of fertilizer recommendations. FAO soil bulletin 38/2. Food and Agriculture Organization of the United Nations, Rome, Italy. F.A.O. Soils Bulletin, No.38/2, pp.118.

5. Fesha, I.G., Shaw, J.N., Reeves, D.W., Wood, C.W., Feng, Y., Norfleet, M.L. \& Van Santen, E. (2002). Land use effects on soil quality parameters for identical soil taxa. In: van Santen E. (Ed.), Making conservation tillage conventional: Building a future on 25 years of research (ed E. van Santen), 25, pp. 233-238. Alabama Agricultural Experimental Station and Auburn University, Alabama,L USA. pp. 233-238.

6. Gregory, A.S., Ritz, K., McGrath, S.P., Quinton, J.N., Goulding, K.W.T., Jones, R.J.A. \& Whitmore, A.P. (2015). A review of the impacts of degradation threats on soil properties in the UK. Soil Use and Management, 31(S1), 1 --15. https://doi.org/10.1111/sum.12212

7. Grogan, P., Lalnunmawia, F. \& Tripathi, S.K. (2012). Shifting cultivation in steeply sloped regions: a review of management options and research priorities for Mizoram state, Northeast India. Agroforestry Systems, 84(2), 163-177. https://doi.org/10.1007/s10457-011-9469-1

8. Hauchhum, R. \& Tripathi, S. K. (2017). Rhizosphere effects of Melocanna baccifera on soil microbial properties under different fallow phases following shifting cultivation. International Journal of Plant \& Soil Science 17(1), 1-9. http://dx.doi.org/10.9734/IJPSS/2017/34493

9. India State of Forest Report (2019). India State of Forest Report (ISFR). http://fsi.nic.in/isfr2019/mizoram-isfr-201 9.pdf.

10. Kiflu, A. \& Beyene, S. (2013). Effects of different land use systems on selected soil properties in South Ethiopia. 
Journal of Soil Science and Environment Management, 4 (5), 100-107. http://dx.doi.org/10.5897/JSSEM12.20

11. Lal, R. (2009). Soils and world food security. Soil Tillage Research. 102(1), 1-4. http://dx.doi.org/10.1016/j.still.2 00 8.08.001

12. Lal, R. (2001). Soil degradation by erosion. Land Degradation and. Development. 12(6), 519--539. https:// doi.org/10.1002/ldr.472

13. Lalnunzira, C. \& Tripathi, S.K. (2018). Leaf and root production, decomposition and fluxes of carbon and nitrogen during stand development in tropical moist forests, northeast India. Soil Research, 56, 306-317. http://dx.doi.org/1 $0.1071 /$ SR16265

14. Loria, N., Bhardwaj, S.K., \& Ndungu, C.K. (2016). Impact of cropping systems on soil properties, nutrient availability and their carbon sequestration potential in Shiwalik Hhills of Himachal Pradesh. Journal of Applied and Natural Science, 8(3), 1479-1484. https://doi.org/10.31018/jans.v $8 \mathrm{i} 3.987$

15. Lumbanraja, J., Syam, T., Nishide, H., Mahi, A.K., Utomo, M., Kimura, S. \& Kimura, M. (1998). Deterioration of soil fertility by land use changes in South Sumatra, Indonesia: from 1970 to 1990. Hydrological Processes, 12(13-14), 2003-2013. https://doi.org/10.1002/(SICI)1099-1085(199 81030)12:13/14<2003::AID HYP715>3.0.CO;2-D

16. Lungmuana, Singh, S.B., Vanthawmliana, Saha, S., Dutta, S.K., Rambuatsaiha, Singh, A.R. \& Boopathi, T. (2017). Impact of secondary forest fallow period on soil microbial biomass carbon and enzyme activity dynamics under shifting cultivation in north eastern hill region, India. Catena, 156, 10-17. https://doi.org/10.1016/j.catena.2017.0 3.017

17. Manpoong, C. \& Tripathi, S.K. (2019). Soil properties under different land use systems of Mizoram, North East India. Journal of Applied and Natural Science, 11(1), 121125. https://doi.org/10.31018/jans.v11i1.1999

18. Moraes, J.F.L., Volkoff, B., Cerri, C.C. \& Bernoux, M. (1996). Soil properties under Amazon forest and changes due to pasture installation in Rondôonnia, Brazil. Geoderma, 70 (1), 63--81. https://doi.org/10.1016/0016-7061 (95)00072-0

19. Nega, E. \& Heluf, G. (2009). Influence of land use changes and soil depth on cation exchange capacity and contents of exchangeable bases in the soils of Senbete watershed, Western Ethiopia. Ethiopian Journal of Natural Resources, 11(2), 195-206.

20. Ovung, E.Y. \& Tripathi S.K. (2020). Recovery of Soil Carbon and Nutrients in Forest Chronosequence Following Jhum cultivation in Mizoram, Northeast India. Environment and Ecology, 38(3A), 569-577.

21. Ovung, E.Y., Kumar, K.S., Manpoong, C., Tripathi, S.K., Khanduri, V.P. \& Singh S.K. (2020): Influence of land-use pattern on soil quality in a steeply sloped tropical mountainous region, India. Archives of Agronomy and Soil Science, https://doi.org/ 10.1080/03650340.2020.1858478

22. Pacheco, F.A.L., Sanches Fernandes, L.F., Valle Junior, R.F., Pissarra, T.C.T. \& Valera, C.A. (2018). Land degradation: multiple environmental consequences and routes to neutrality. Current Opinion in Environmental Science \& Health, 5, 79--86. https://doi.org/10.1016/j.coesh.2 018.07 .002

23. Peech, M. (1965). Hydrogen-ion activity. In: Black, C.A
(Ed.), Methods of Soil Analysis, Part 2, Chemical and Microbiological Properties Vol 9. American Society for Microbiology, Agronomy, Madison, Wisconsin, USA. pp. 914-9265. https://doi.org/10.2134/agronmonogr9.2.c9

24. Pricope, N.G., Husak, G., Lopez-Carr, D., Funk, C. \& Michaelsen, J. (2013). The climate population nexus in the East African Horn: emerging degradation trends in rangeland and pastoral livelihood zones. Global Environmental Change, 23(6), 1525-1541. https://doi.org/10.1016/j.gloen vcha.2013.10.002

25. Ramakrishnan, P.S. \& Kushwaha, S.P.S. (2001). Secondary forests of the Himalaya with emphasis on the northeastern hill region of India. Journal of Tropical Forest Science, 13(4), 727-747. https://www.jstor.org/stable/435 82369

26. Sarkar, U.K., Saha, B.K., Goswami, C. \& Chowdhury, M.A.H. (2010). Leaf litter amendment in forest soil and their effect on the yield quality of red amaranth. Journal of Bangladesh Agriculture Univerisity, 8(2), 221-226. https:// doi:10.3329/jbau.v8i2.7929

27. Singh, S.B., Mishra, B.P. \& Tripathi, S.K. (2015). Recovery of plant diversity and soil nutrients during stand development in subtropical forests of Mizoram. Northeast India, Biodiversitas, 16(2), 205-212. https://doi.org/10.13057/ biodiv/d160216

28. Singha, D. \& Tripathi, S.K. (2017). Variations in fine root growth during age chronosequence of moist tropical forest following shifting cultivation in Mizoram, northeast India. Tropical Ecology, 58(4), 769-779.

29. Tekalign, M., Richter, C. \& Heiligtag, B. (2002). Phosphorus availability studies on ten Ethiopian Vertisols. Journal of Agriculture and Rural Development in the Tropics and Subtropics, 103(2), 177-183.

30. Tripathi, S.K., Kushwaha, C.P. \& Basu, S.K. (2012). Application of fractal theory in assessing soil aggregates in Indian tropical ecosystems. Journal of Forestry Research 23(3),: 355-364. https://doi.org/10.1007/s11676-012-02713

31. Tripathi, S.K., Vanlalfakawma, D.C. \& Lalnunmawia, F. (2017). Shifting cultivation on steep slopes of Mizoram, India: Impact of policy reforms. In: Cairns M. (Eed.), Shifting Cultivation Policies: Balancing Environmental and Social Sustainability: CABI International Publishing, London. pp 393-413. https://doi.org/10.1079/9781786391 797.0393

32. Tully, K., Sullivan, C., Weil, R. \& Sanchez, P. (2015). The state of soil degradation in Sub-Saharan Africa: baselines, trajectories, and solutions. Sustainability, 7(6), 65236552. https://doi.org/10.3390/su7066523

33. Ufot, U.O., Iren, O.B. \& Chikere Njoku, C.U. (2016). Effects of land use on soil physical and chemical properties in Akokwa area of Imo State, Nigeria. International Journal of Life Sciences Scientific Research, 2(3), 273-278. https://doi:10.21276/ijlssr.2016.2.3.14

34. Valera, C.A., Valle Junior, R.F., Varandas, S.G.P., Sanches Fernandes, L.F. \& Pacheco, F.A.L. (2016). The role of environmental land use conflicts in soil fertility: a study on the Uberaba River basin, Brazil. Science of the Total Environment, 562, 463-473. https://doi.org/10.1016/ j.scitotenv.2016.04.046

35. Valle Junior, R.F., Varandas, S.G.P., Sanches Fernandes, L.F. \& Pacheco, F.A.L. (2014). Environmental land use 
conflicts: a threat to soil conservation. Land Use Policy, 41,172-185. https://doi.org/10.1016/j.landusepol.2014.0 5.012

36. Voundi Nkana, J.C. (1998). Use of wood industry wastes for improving chemical fertility in tropical acid soils. University of Gent, Belgium.

37. Wapongnungsang., Adangnaro. \& Tripathi, S.K. (2018). Effects of dDifferent land use systems on Soil Carbon and Nitrogen Dynamics in Zunheboto District of Nagaland, Northeast India. Indian Journal of Ecology, 45(4), 831834.

38. Wapongnungsang., Hauchhum. R. \& Tripathi, S.K. (2017). Litter decomposition vVis-a-vVis carbon and nitrogen dynamics of Tephrosia candida components in different fal- low periods following shifting cultivation in Mizoram. Indian Journal of Ecology, 44(4), 791-796.

39. $\mathrm{Wu}$, Q. (2011). Environmental edaphology [M]. Beijing: Chinese Agricultural Press, Beijing, China:. pp. 82-83.

40. Yihenew, G. \& Getachew, A. (2013). Effects of different land use systems on selected physicochemical properties of soils in Northwestern Ethiopia. Journal of Agricultural Science, 5(4), 112-120. https://doi.org/10.5539/jas.v5n4p 112

41. Yimer, F., Ledin, S. \& Abdelkadir, A. (2008). Concentrations of exchangeable bases and cation exchange capacity in soils of cropland, grazing and forest in the Bale Mountains, Ethiopia. Forest Ecology and Management, 256(6), 1298-1302. https://doi.org/10.1016/j.fore co.2008.06.047 